\title{
GROUND SHAKING INTENSITY AND DAMAGE AT LAKE COLERIDGE POWER STATION IN THE 18 JUNE 1994 AVOCA RIVER EARTHQUAKE
}

\author{
A. Pattle ${ }^{1}$ and J.H. Wood ${ }^{2}$
}

\begin{abstract}
Apart from highway bridges and embankments, the only major structures close to the epicentre of the 18 June 1994 Avoca River magnitude ML 6.5 were at the Lake Coleridge hydo power scheme. At the power-house location, the peak ground acceleration reached $0.14 \mathrm{~g}$ and the felt intensity was estimated as MMI VII.

Because most of the buildings and civil structures at the scheme are more than 60 years of age their performance under the moderate level of shaking was of particular interest. Damage to the buildings and other structures was minor and it is thought that the ground shaking intensity was just below the threshold level above which more serious damage might be expected.
\end{abstract}

\section{INTRODUCTION}

The 34.4 MW Lake Coleridge hydro power scheme is located about $85 \mathrm{~km}$ west of Christchurch in the foothills of the Southern Alps. The power-house structures were the only major buildings within a $50 \mathrm{~km}$ radius from the 18 June 1994 Avoca River earthquake (also referred to as the Arthurs Pass earthquake) that was centred about $20 \mathrm{~km}$ southwest of the Arthurs Pass.

The power scheme makes use of the $165 \mathrm{~m}$ head between Lake Coleridge and the Rakaia River with water transported from the lake intakes through two $2 \mathrm{~km}$ long tunnels and steel penstocks to the station's nine generators. Two concrete surge chamber structures are located at the top of the penstock slope: Diversion structures at the Acheron and Wilberforce Rivers increase the natural inflow to Lake Coleridge.

Most of the power scheme structures were built between 1911 and 1925 and so were not specifically designed to resist earthquake loads. Recent assessments have shown that a number of the structures do not meet currently accepted earthquake safety standards. In addition, the mechanical and electrical plant is nearing the end of its economic life. The Electricity Corporation of New Zealand Ltd (ECNZ), is proposing to proceed with refurbishment and structural strengthening work in a number of stages. The seismic strengthening of the power-house buildings will form part of this work.

Because of the recognised strengthening and refurbishment needs of the power station, the ground shaking intensity and the effect on the structures of the 18 June 1994 Avoca River earthquake was of particular interest.

\footnotetext{
1 Waitaki Hydro Group, Electricity Corporation of NZ Ltd.
}

2 Phillips \& Wood Ltd. (Fellow)

\section{GROUND SHAKING INTENSITY}

The power-house buildings were approximately $35 \mathrm{~km}$ from the epicentre of the magnitude (ML) 6.5 earthquake . Two major aftershocks of magnitude 5.8 and 5.6 occurred in the Harper River area much closer to Lake Coleridge. Locations of the epicentre and these main aftershocks are shown in Figure 1 of the accompanying paper by Patterson and Bourne-Webb (1994). The power station is on the west side of Lake Coleridge close to the lower border of this Figure.

The felt intensity near the buildings of the main shock was estimated to be MM VII. A scratch plate recorder located in the basement of the power-house gave a peak ground acceleration (PGA) of $0.135 \mathrm{~g}$ with NS and EW maximums of 0.13 and $0.11 \mathrm{~g}$ respectively.

NZS 4203: 1992 code of practice for design loadings on buildings gives a 450 year return period PGA of $0.38 \mathrm{~g}$ for the Coleridge area. Therefore, in terms of PGA, the ground shaking intensity only reached about one-third of the current design standard.

\section{PREVIOUS EARTHQUAKES}

Since construction of the power station, the site has been shaken by two earthquakes that reached MMI VI or greater. The first of these was the 9 March 1929 Arthurs Pass earthquake that produced MMI VI at the site. The second was the 26 June 1946 Lake Coleridge earthquake that reached MMI VII [Eiby, 1990].

This latter earthquake broke a significant number of windows in the exterior walls of the power-house and opened some of the expansion joints in the penstocks. No significant structural damage was reported. Prior to construction of the scheme, the 31 August 1888 Glynn Wye earthquake shook the site. with an estimated MMI of VI. 


\section{INTERRUPTION TO GENERATION}

The 18 June 1994 earthquake tripped three generators and two transformers. Five other generators were tripped manually by the Station Operator. One generator was out of action because a stator winding was being replaced at the time of the earthquake.

Visual inspections carried out on the station, switch yard, penstocks and surge chambers revealed only minor damage. Soon after the earthquake, the station was progressively placed back on load with all eight in-service generators achieving maximum load within about $1 \mathrm{hr} 40 \mathrm{~min}$ of the earthquake.

\section{POWER HOUSE BUILDINGS}

The two buildings which make up the power-house were constructed as separate structures with a separation gap of about $50 \mathrm{~mm}$. The original power house, Building ' $A$ ', is $55 \mathrm{~m}$ long by $22 \mathrm{~m}$ wide and was constructed in 1914. Building ' $\mathrm{B}$ ' was built in 1925 as an extension to the generator hall of the first building and is $47 \mathrm{~m}$ long by $11 \mathrm{~m}$ wide.

Typical details of the buildings are shown in Figure 1. Both buildings are of similar reinforced concrete frame construction with concrete beams supporting a $100 \mathrm{~mm}$ thick reinforced concrete roof. The original concrete roofs were later more securely weather proofed by the addition of galvanised steel roofing placed on a light weight structure over the top of concrete.

The perimeter walls of both buildings consist of a series of full height reinforced concrete columns spaced at $4.6 \mathrm{~m}$. Smaller section concrete window mullions are located mid-way between the main columns. Reinforced concrete walls built monolithically with, and spanning between the columns, extend from the main floor levels to the underside of the windows in the walls. Crane rail beams are supported on corbels near the tops of the generator hall columns. Reinforced concrete parapets and cornices extend around the perimeter of the roof.
In both buildings, transverse and longitudinal direction lateral loads are carried by frame action. Because of monolithic walls in both the exterior and interior longitudinal column lines, the buildings are stiffer in the longitudinal direction than in the transverse direction

The main walls are founded on spread footings which are tied transversely across the building by ground floor slabs and the generator hall galleries.

The site consists of glacial and fluvioglacial deposits making up a moraine formed by the last major glacial advance in the Rakaia Valley. Foundation soils are largely silts interspersed with gravel layers. For seismic load assessment, the foundation soil layers were considered to be flexible.

\section{DAMAGE TO POWER HOUSE BUILDINGS}

Only very minor damaged occurred to the power-house buildings. Damage details were recorded as follows:

- There were approximately 100 broken or cracked windows. Loss of glass was predominantly from the west end wall of Building ' $\mathrm{B}$ '.

- Concrete was spalled by clashing of the buildings at the joint between them but the damage was superficial.

- An offset of $10 \mathrm{~mm}$ occurred at the joint in the crane rails where they join between the two buildings.

- A number of fine cracks were observed in the concrete walls and typically extended from the lower window sills to the floor. Many of the cracks were related to repaired pre-existing cracks that were caused by shrinkage, settlement or possibly previous earthquake activity but some new cracks formed. However, most of the cracks that opened had widths considerably less than $1 \mathrm{~mm}$.

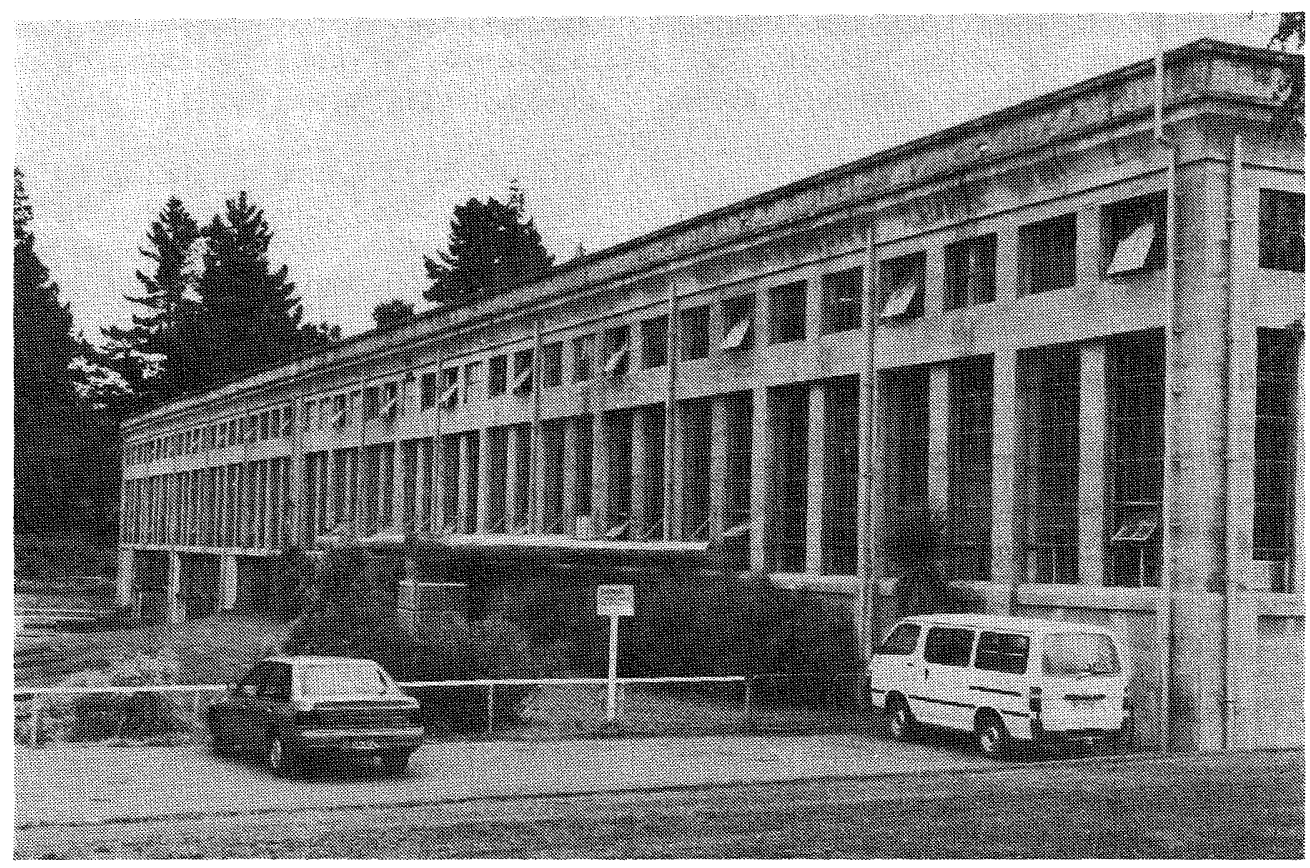

Figure 1. Lake Coleridge power station buildings (tailrace side). 
The damage to the buildings appeared similar to that which occurred in the 1946 earthquake. In 1946 it was reported that 72 windows were broken and minor damage occurred at the joint between the two buildings. In 1946 a number of penstock expansion joints opened but no movement of the joints was observed in the recent earthquake.

Because of the absence of transverse walls at the junction between the buildings, both buildings have a lack of symmetry for transverse lateral loads. An analysis of the Building ' $B$ ' carried out prior to the earthquake indicated that the west end wall carried a significantly greater load than the interior frames and would be the most vulnerable structural component. The windows are in steel frames that are rigidly connected to concrete columns and mullions. In view of the analysis findings and the window details, the damage to the end wall windows was not unexpected.

\section{HYDRAULIC STRUCTURES}

There were no signs of damage to the hydraulic structures which include the intakes, surge tanks and penstocks.

Drainage flows discharging artesian water on the lower penstock slope were carrying silt immediately following the earthquake. The flows were not excessive and have carried silt in the recent past so gave no cause for immediate concern.

Two small sinkholes formed in the fill between the downstream wall of the power houses and the tailrace weirs.

\section{HARPER AND WILBERFORCE DIVERSIONS}

The Harper and Wilberforce diversion structures and canals are located about $15 \mathrm{~km}$ closer to the epicentre than the power station. The earthquake was felt more strongly at Harper than at the power station but was assessed as having the same MM VII intensity. The magnitude 5.8 aftershock with an epicentre very close to Harper was also strongly felt.

In the main shock the house occupied by the Harper Plant Operator received very minor damage to a brick veneer gable. The contents of the house were not greatly disturbed. In the maggnitude 5.8 aftershock a large section of the gable end was dislodged as shown in Figure 2. A wood burner fireplace was also dislodged with the flue movement resulting in damage to the ceiling.

At Glenthorn station, about $2 \mathrm{~km}$ closer to the epicentre of the mainshock than the diversion structures, the house contents ended in disarray with a microwave oven and shelf contents falling to the floor in the main event.

In the main shock a number of canal slopes suffered minor slumping. In the aftershock, additional slumping occurred and there was some minor differential settlement in the fill covering a corrugated steel culvert structure. Some of the damage is illustrated in Figure 3. The canal slope slumping and settlement was the only observed damage to ECNZ structures at this location.

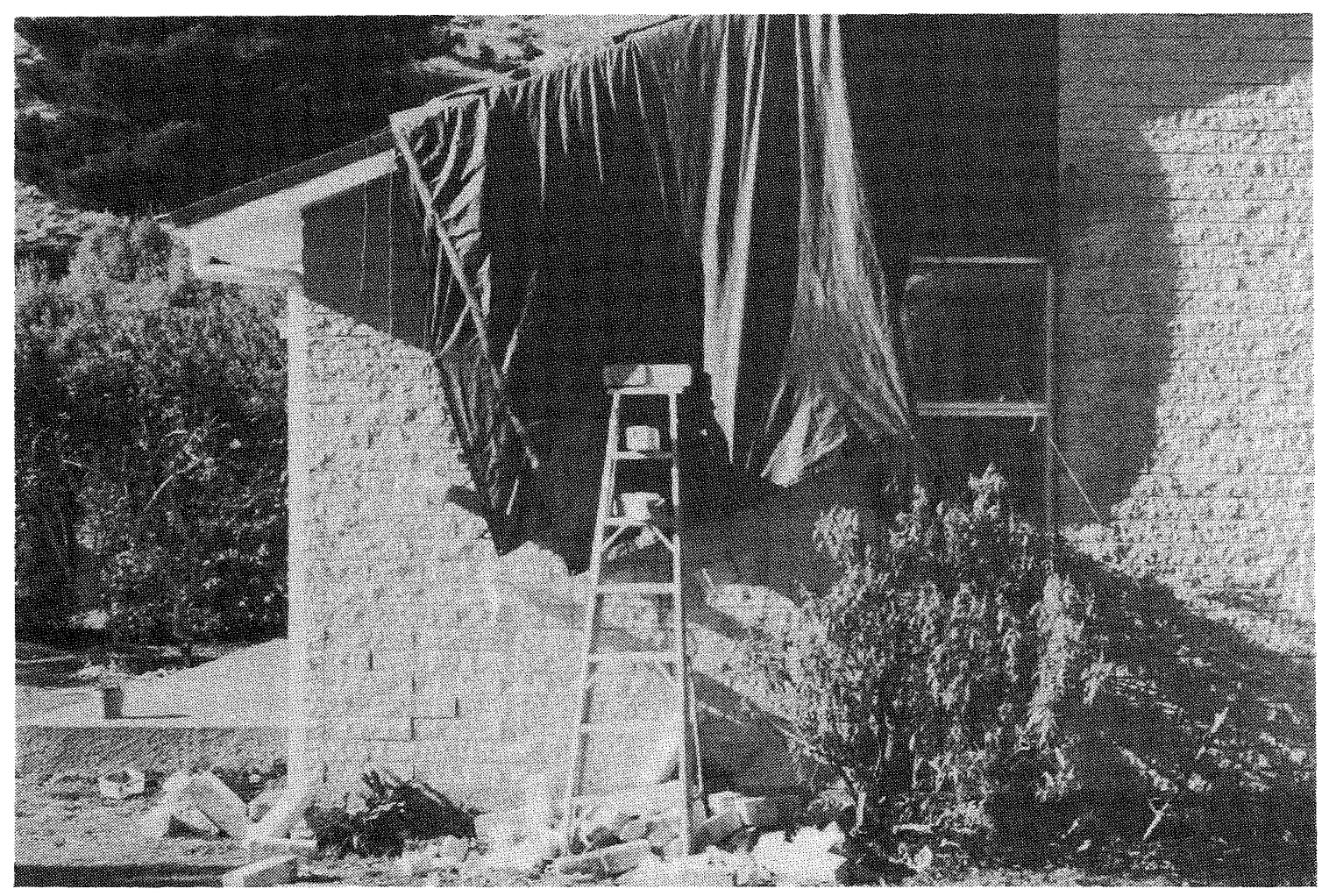

Figure 2. Section of gable end dislodged at the Plant Operators residence, Harpers Village, in the magnitude 5.8 aftershock. 


\section{HIGHBANK POWER STATION}

At the Highbank Power Station, located to the east of Lake Coleridge and about $60 \mathrm{~km}$ from the epicentre, the felt intensity was estimated to be MMI V.

The generation at the plant was tripped during the main event by spurious operation of the transformer Buckholz relays. Several pieces of shotcrete were dislodged from the penstock slope protection. However, the slope protection had been previously identified as requiring remedial work.

\section{CONCLUSION}

Although the older structures of the Lake Coleridge Power Station have not been specifically designed for earthquakes, they did not sustain any significant damage in the moderate level of ground shaking experienced in the Avoca River earthquake and the similar intensity shaking of the 1946 Arthurs Pass earthquake.
It seems likely that the MMI VII ground shaking intensity with a PGA of about $0.14 \mathrm{~g}$ is just below the threshold level above which more serious damage can be expected. Knowledge of this damage threshold level is useful in making earthquake risk assessments for the Lake Coleridge scheme and other older power station facilities.

\section{REFERENCE}

Eiby, G. 1990. The Lake Coleridge Earthquakes of 1946, Bull. of N.Z. National Society for Earthquake Engineering, 23(2):150158.

Patterson, B.R. and Bourne-Webb, P.J. 1994. Reconnaissance report on highway damage from the 18 June 1994, Arthurs Pass Earthquake, Bull. of N.Z. National Society for Earthquake Engineering, 27(3):222-226.

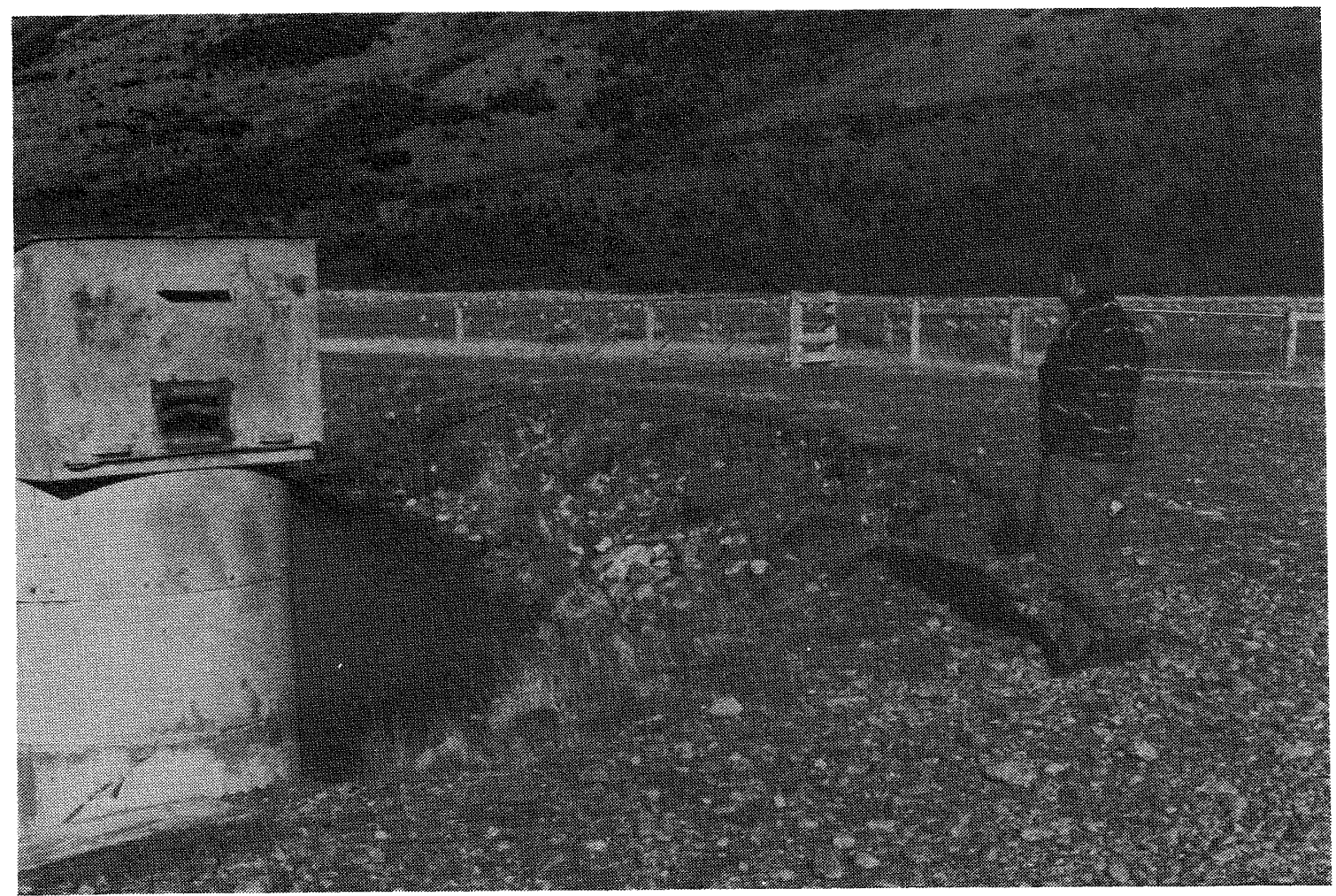

Figure 3. Embankment slumping at Oakden Culvert, Wilberforce Diversion. 